\title{
PENGARUH KOSENTRASI CMC DAN LAMA PEMANASAN TERHADAP SIFAT FISIK DAN KIMIA (LIKOPEN) SARI BUAH TOMAT
}

\section{INFLUENCE OF CMC CONCENTRATION AND THE DURATION OF HEATING ON THE PHYSICAL AND CHEMICAL PROPERTIES (LYCOPENE) OF TOMATO JUICE}

\author{
Anas Suyuti ${ }^{1)}$, Moh. Su'i ${ }^{1)}$, Sudiyono ${ }^{1)}$ \\ ${ }^{1)}$ Fakultas Pertanian Universitas Widyagama Malang \\ Email: anassuyuti@yahoo.co.id
}

\begin{abstract}
ABSTRAK
Sari Buah Tomat adalah produk minuman berbentuk cair dibuat dari buah tomat matang dan segar yang memiliki nilai gizi dan manfaat bagi tubuh salah satunya likopen. Likopen merupakan karotenoid pemberi warna merah pada buah tomat. Likopen berfungsi sebagai antioksidan kuat dalam mengendalikan radikal bebas. Tujuan penelitian ini adalah untuk mengetahui pengaruh kosentrasi CMC dan lama pemanasan terhadap sifat fisik dan kimia (likopen) sari buah tomat. Penelitian ini merupakan jenis penelitian eksperimental yang disusun menggunakan Rancangan Acak Lengkap (RAL) dengan menggunakan dua faktor dan disusun secara faktorial. Faktor pertama adalah konsentrasi CMC yaitu $0.1 \%, 0.15 \%$ dan $0.2 \%$. Faktor kedua adalah lama pemanasan yaitu 10 menit, 15 menit, 20 menit dan 30 menit. Masing-masing perlakuan diulang sebanyak tiga kali. Hasil penelitian adalah kadar likopen antara $3.768 \mathrm{mg} / 100 \mathrm{ml}-1.436$ $\mathrm{mg} / 100 \mathrm{ml}$, viskositas $7.30 \mathrm{cp}-17.20 \mathrm{cP}, \mathrm{pH} 3.992-4.051$, nilai warna merah (a*) 13 32 - 13.95, dan organoleptik rasa (rangking) 53.83 - 134.40, warna 67.00 - 120.30 dan aroma 73.63 - 117.53 .
\end{abstract}

Kata Kunci: CMC, likopen, pemanasan, sari buah, tomat

\begin{abstract}
Tomato juice is a liquid beverage product which made from ripe and fresh tomatoes that have nutritional value and benefits for the body which is lycopene. Lycopene is a red colour of carotenoid in tomatoes. Lycopene is function as a strong antioxidant to control free radicals. The purpose of this study was to know the effect of $\mathrm{CMC}$ concentration and the duration of heating on the physical and chemical properties (lycopene) of tomato juice. This research was an experimental research that used Completely Randomized Design (RAL) with two factors and was arranged factorially. The first factor was the concentrations of CMC that were $0.1 \%, 0.15 \%$, and $0.2 \%$. The second factor was durations of heating that were 10 minutes, 15 minutes, 20 minutes and 30 minutes. Each treatment was repeated three times. The results of the study was lycopene content was $3,768 \mathrm{mg} / 100 \mathrm{ml}-1,436 \mathrm{mg} / 100 \mathrm{ml}$, viscosity was $7.30 \mathrm{cp}-17.20$
\end{abstract}


cP, pH 3,992 - 4,051, red color value was (a *) 1332 - 13.95, and organoleptic taste (rank) 53.83 - 134.40, color 67.00 - 120.30 and aroma 73.63 - 117.53.

Keywords : CMC, heating, juice, lycopene, tomato

\section{PENDAHULUAN}

Buah tomat merupakan komoditas hortikultura yang mempunyai prospek yang baik bila dikembangkan secara intensif. Tomat merupakan salah satu tanaman hortikultura yang digolongkan ke dalam sayuran buah, Tanaman ini banyak di budidayakan petani, karena buah tomat mudah dibudidayakan dan cocok ditanam di iklim Indonesia (Astuti, 2004)

Tomat termasuk tanaman dalam famili solanaceae. Tanaman tomat banyak ditanam di dataran tinggi, dataran sedang, dataran rendah. Tanaman ini merupakan tanaman semusim yang berumur sekitar 4 bulan. Tanaman tomat dapat ditanam sepanjang tahun. Namun, waktu yang paling baik untuk menanam tomat adalah musim kemarau yang dibantu dengan penyiraman secukupnya. Pada waktu musim kemarau banyak petani yang menanan tomat sehingga harganya rendah. Pada waktu musim hujan tidak banyak petani yang menanam tomat sehingga harga tomat melonjak sangat tinggi (Pracaya, 1998)

Tomat merupakan buah sayur yang kaya akan berbagai senyawa anti oksidan seperti likopen, alfa karoten, beta karoten, lutein, vitamin $\mathrm{C}$, flavonoid, dan Vitamin E. Likopen merupakan anti oksidan kuat, yang terdapat pada tomat dan produk tomat. Hasil penelitian menemukan bahwa likopen dapat membantu mengurangi beberapa penyakit kanker dan jantung. Sejauh ini bukti paling menyakinkan adalah likopen berperan mencegah kanker prostat (Tsang, 2006)

Tomat (Lycopersicum esculentum Mill) termasuk buah klimakterik, yaitu buah yang mengalami kenaikan respirasi setelah dipanen sehingga dapat matang sempurna setelah dipanen. Komponen tertinggi dari buah tomat adalah air (lebih dari 90\%) sehingga buah tomat tergolong komoditas yang 
sangat mudah rusak (Very perishable). (Purwadi, dkk, 2007)

Untuk mengatasi masalah tersebut bisa dilakukan pengolahan terhadap buah tomat menjadi sari buah tomat sehingga mempunyai nilai tambah dan waktu simpan yang relatif lama.

Definisi sari buah menurut Keputusan Kepala Badan Pengawasan Obat dan Makanan Nomer HK. No. HK.00.05.4040 tahun 2006 tentang katagori pangan adalah cairan yang diperoleh dari bagian buah yang dapat dimakan yang dicuci, dihancurkan, dijernihkan (jika dibutuhkan), dengan atau tanpa pasteurisasi dan dikemas untuk dikonsumsi langsung. (POM, 2006)

Menurut Standar Nasional Indonesia (1998) sari buah tomat didefinisikan dengan produk minuman yang diperoleh secara mekanis dari buah tomat (Lycopersicum sp) matang tanpa kulit dan biji atau dari pengenceran kosentrat buah tomat, tanpa fermentasi, diawetkan, dan dengan atau tanpa penambahan bahan tambahan makanan yang diizinkan. (SNI, 1998)

Proses pembuatan sari buah tomat dengan menggunakan pemanasan bisa menyebabkan sari buah tomat kehilangan zat aktif berkhasiat terutama likopen. Sari buah tomat juga mengalami pemisahan padatan secara bertahap setelah proses selesai. Penambahan CMC akan mencegah pemisahan bahan padatan dalam sari buah tomat. Oleh karena itu dibutuhkan metode yang bisa mencegah terjadinya kehilangan senyawa likopen dan pemisahan bahan padatan dalam sari buah tomat dengan cara mengoptimasi lama pemanasan dan penambahan $\mathrm{CMC}$ yang tepat agar didapat kualitas sari buah tomat dan kadar likopen yang maksimal.

Likopen merupakan pigmen yang terdapat dalam tumbuhan yang sering di kenal dengan karotenoid yang menghasilkan warna kuning orange dan merah (Story, dkk. 2010). Likopen memberi banyak manfaat bagi manusia antara lain untuk menjaga kesehatan kulit, rambut, dan juga mencegah beberapa penyakit seperti penyakit jantung, kanker prostat, stroke. (Radhakrisnan, 2017). Dengan mengkomsumsi likopen secara teratur dapat menurunkan resiko kanker prostat likopen juga dapat mencegah 
pertumbuhan dari proses perkembang biakan sel kanker prostat (Jevic, 2003).

Likopen yang mempunyai banyak manfaat bagi kehidupan manusia memiliki beberapa kelemahan yang menyebabkan likopen mengalami kerusakan. Likopen adalah pigmen yang tidak stabil dan dapat terdegradasi oleh panas, cahaya, dan oksigen melalui isomerisasi dan oksidasi (Oberoi,2015). Hal yang sama diungkapkan oleh Shi dkk bahwa, buah tomat segar mengandung likopen dengan kosentrasi tinggi. Kondisi pengolahan seperti suhu tinggi, waktu proses yang lama dan oksigen telah terbukti memiliki efek pada degradasi likopen (Shi, 1999). Untuk itu perlu dilakukan penelitian agar manfaat likopen sari buah buah tomat bisa di manfaatkan secara maksimal dengan cara melakukan optimasi lama pemanasan.

Penelitian bertujuan untuk mengetahui pengaruh kosentrasi CMC dan lama pemanasan terhadap sifat fisik dan kimia (Likopen) sari buah tomat

\section{METODOLOGI PENELITIAN}

Bahan yang digunakan dalam penelitian ini meliputi: Buah tomat yang di dapat dari pasar Porong Sidoarjo, gula pasir, air, CMC (carboxy methyl cellulose), Asam sitrat dan $\mathrm{Na}$ benzoat, Hexan dan Standard likopen.

Alat-alat yang digunakan pembu atan sari buah tomat yaitu pisau, Blander, saringan 30 mesh, baskom, beker glas $5000 \mathrm{ml}$, glas ukur $1000 \mathrm{ml}$. Sedangkan alat-alat yang digunakan untuk analisa adalah timbangan Semi Mikro Balance Metler Toledo XP205, labu ukur, pipet tetes, tes tube $50 \mathrm{ml}$ lengkap dengan penutup, Vortek Thermolyne M37610-26, Stopwatch, Waterbath Memmert WNB7, pH-meter Metler Toledo Seven Compact SCS220K, Colorimeter Hunterlab Ultra scan Vis 1297, Viskometer Anton Paar MCR1， Spektrofotometer UV 1800 Shimadzu.

\section{Rancangan percobaan}

Penelitian ini menggunakan meto de experimental dengan dua faktor yang disusun secara faktorial. Rancangan percobaan menggunakan Rancangan Acak Lengkap (RAL). Faktor pertama adalah kosentrasi CMC yang digunakan dalam pembuatan sari buah tomat dengan tiga level yaitu $0.1 \%, 0,12 \%$ dan 
0.2\%. Faktor kedua adalah lama pemanasan dalam proses pembuatan sari buah tomat dengan empat level yaitu 10 menit, 15 menit, 20 menit, 30 menit. Masing - masing perlakuan dilakukan tiga kali pengulangan. Data hasil penelitian diuji dengan analisis ragam dan dilanjutkan dengan uji BNT.

\section{Pelaksanaan Penelitian}

\section{Pembuatan Sari Buah Tomat}

Sari buah tomat dibuat dengan cara mencuci buah tomat hingga bersih. Tomat yang sudah bersih kemudian dipotong dan dihancurkan dengan menggunakan blander dan disaring (30 mesh) sehingga diperoleh perasan sari tomat. Perasan sari tomat yang diperoleh diukur volumenya dan disimpan. Kemudian ampas ditambah kan air matang sebanyak dua kali volume dari hasil perasan sari tomat dan diaduk hingga merata kemudian disaring (30 mesh). Perasan sari tomat hasil penyaringan pertama dan kedua jadikan satu. Kemudian tambahkan gula pasir $13 \%$, natrium benzoat $0.06 \%$, asam sitrat $0.1 \%$ dan bahan penstabil CMC (Carboxy Methyl Cellulose) sebanyak $0.1 \%, 0,15 \%$ dan $0.2 \%$.
Selanjutnya diaduk sampai bahanbahan tambahan tercampur selanjutnya dipanaskan pada suhu $80^{\circ} \mathrm{C}$ selama 10 menit, 15 menit, 20 menit, dan 30 menit. Setelah itu, sari buah dikemas dalam botol yang telah disterilisasi dalam kondisi masih panas.

\section{Analisis Sari Buah Tomat}

Sari buah tomat yang telah dibuat kemudian dianalisis yang meliputi uji kadar likopen dengan menggunakan spektrofotometer, uji viskositas dengan menggunakan visko meter, uji $\mathrm{pH}$ dengan menggunakan $\mathrm{pH}$ meter, uji warna dengan menggunakan colorimeter dan uji organoleptik dengan menggunakan 15 panelis.

\section{HASIL DAN PEMBAHASAAN}

\section{Kadar Likopen Sari Buah Tomat}

Dari hasil pengamatan yang dilakukan terhadap kadar likopen sari buah tomat, diperoleh kadar likopen rata-rata berkisar $3.768 \mathrm{mg} / 100 \mathrm{ml}$ $1.436 \mathrm{mg} / 100 \mathrm{ml}$. Kadar likopen sari buah tomat tertinggi terdapat pada perlakuan penambahan CMC $0.10 \%$ dengan pemanasan 10 menit yaitu 3.768 mg/100 ml, sedangkan kadar likopen 
sari buah tomat terendah terdapat pada perlakuan penambahan CMC $0.20 \%$ dengan pemanasan 30 menit yaitu 1.436 $\mathrm{mg} / 100 \mathrm{ml}$.

Hasil analisis statistik Anova bahwa kosentrasi CMC dan lama pemanasan memberikan pengaruh yang nyata dan menunjukan adanya interaksi antara kosentrasi CMC dan lama pema nasan terhadap kadar likopen. Interaksi antara kosentrasi CMC dan lama pemanasan terhadap kadar likopen dapat dilihat pada Gambar 1 dan Tabel 1.

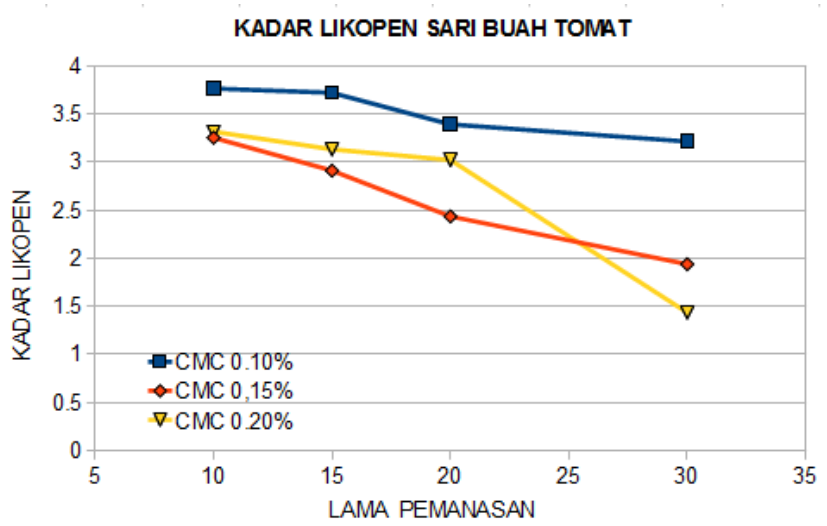

Gambar 1. Kadar likopen sari buah tomat

Gambar 1 menunjukkan bahwa, pada kosentrasi CMC $0.1 \%$ terjadi penurunan kadar likopen dengan semakin lama pemanasan. Sedangkan pada kosentrasi CMC $0.15 \%$ dan $0.2 \%$ penurunan kadar likopen semakin tajam dengan semakin lamanya pemanasan.
Hal ini diduga karena adanya interaksi parsial, semakin tinggi kosentrasi CMC yang ditambahkan maka CMC akan berikatan dengan CMC sehingga menghasilkan likopen bebas dan lebih mudah terdegradasi oleh panas.

Tabel 1. Nilai Rerata Kadar Likopen Sari Buah Tomat

Perlakuan Rerata
kadar likopen

CMC $0.10 \%$ pemanasan 10 menit 3.76771

CMC $0.10 \%$ pemanasan 15 menit

$3.7231 \mathrm{k}$

CMC $0.10 \%$ pemanasan 20 menit $3.3942 \mathrm{j}$

CMC $0.10 \%$ pemanasan 30 menit $3.2158 \mathrm{~g}$

CMC $0.15 \%$ pemanasan 10 menit $3.2551 \mathrm{~h}$

CMC $0.15 \%$ pemanasan 15 menit

$2.9135 d$

CMC $0.15 \%$ pemanasan 20 menit

$2.4364 \mathrm{c}$

CMC $0.15 \%$ pemanasan 30 menit $1.9393 b$

CMC $0.20 \%$ pemanasan 10 menit $3.3180 \mathrm{i}$

CMC $0.20 \%$ pemanasan 15 menit

$3.1348 \mathrm{f}$

CMC $0.20 \%$ pemanasan 20 menit 3.0233 e

CMC $0.20 \%$ pemanasan 30 menit

$1.4360 \mathrm{a}$

Keterangan:

Nilai yang didampingi huruf berbeda menunjukan hasil yang berbeda nyata pada uji BNJ $(a=0.05)$.

Likopen merupakan senyawa yang tidak stabil dan dapat terdegradasi oleh panas, cahaya, dan oksigen melalui isomerisasi dan oksidasi (Oberoi,2015), Pada Gambar 1 menunjukan bahwa dengan penambahan lama pemanasan 
dan kosentrasi CMC akan menurunkan kadar likopen.

\section{Vikositas Sari Buah Tomat}

Berdasarkan data hasil penelitian, viskositas sari buah tomat berkisar antara $7.30 \mathrm{cP}-17.20 \mathrm{cP}$. Viskositas sari buah tomat tertinggi terdapat pada perlakuan penambahan CMC $0.20 \%$ dengan pemanasan 30 menit yaitu 7.30 cP, sedangkan hasil Viskositas sari buah tomat terendah terdapat pada perlakuan penambahan $\mathrm{CMC} \quad 0.10 \%$ dengan pemanasan 10 menit yaitu $7.30 \mathrm{cp}$.

Hasil analisis statistik Anova menunjukan penambahan kosentrasi CMC berpengaruh nyata terhadap nilai viskositas. Lama pemanasan tidak berpengaruh nyata terhadap nilai viskositas. Tidak ada interaksi antara kosentrasi dan lama pemansan terhadap nilai $\mathrm{pH}$. Pengaruh kosentrasi $\mathrm{CMC}$ terhadap nilai viskositas sari buah tomat dapat dilihat pada Tabel 2.

Tabel 2 menunjukkan bahwa, semakin tinggi kosentrasi CMC nilai viskositas semakin meningkat. Menurut Kamal dan Nety (2010), bahwa semakin besar kosentrasi CMC yang di tambahkan dalam sampel dapat meningkatkan kekentalan. Hal serupa juga di nyatakna oleh prayitno (2002), bahwa Penggunaan CMC dalam produk pangan akan meningkatkan kekentalan.

Tabel 2. Nilai Rerata kosentrasi CMC terhadap nilai Viskositas Sari buah tomat

\begin{tabular}{ccc}
\hline $\begin{array}{c}\text { Kosentrasi } \\
\text { CMC }\end{array}$ & Rerata Viskositas (cp) & $\begin{array}{c}\text { Nilai } \\
\text { BNJ }\end{array}$ \\
\hline CMC 0.10\% & $7.48 \mathrm{a}$ & \\
CMC 0.15\% & $11.70 \mathrm{~b}$ & 0.285 \\
CMC 0.20\% & $17.08 \mathrm{c}$ & \\
\hline
\end{tabular}

Keterangan:

Nilai yang didampingi huruf berbeda menunjukan hasil yang berbeda nyata pada uji $\operatorname{BNJ}(\mathrm{a}=0.05)$.

\section{pH Sari Buah Tomat}

Derajat keasaman sari buah tomat menurut SNI 1998 dinyatakan bahwa mutu sari buah tomat dipersyartakan tidak boleh lebih dari 4.0. Hasil penelitian sari buah tomat mempunyai nilai $\mathrm{pH}$ berkisar antara $3.993-4.051$.

Hasil analisis statistik Anova menunjukan bahwa penambahan kosentrasi $\mathrm{CMC}$ berpengaruh nyata terhadap nilai $\mathrm{pH}$. Lama pemanasan tidak berpengaruh nyata terhadap nilai 
pH. Tidak ada interaksi antara kosentrasi dan lama pemansan terhadap pH. Pengaruh kosentrasi CMC terhadap $\mathrm{pH}$ sari buah tomat dapat dilihat pada Tabel 3.

Tabel 3. Pengaruh Penambahan Kosentrasi CMC terha dap $\mathrm{pH}$ sari buah tomat

\begin{tabular}{crc}
\hline Kosentrasi CMC & Rerata pH & Nilai BNJ \\
\hline CMC $0.10 \%$ & $3.994 \mathrm{a}$ & \\
CMC $0.15 \%$ & $4.021 \mathrm{~b}$ & 0.07 \\
CMC $0.20 \%$ & $4.050 \mathrm{c}$ & \\
\hline
\end{tabular}

Keterangan:

Nilai yang didampingi huruf berbeda menunjukan hasil yang berbeda nyata pada uji $\operatorname{BNJ}(a=0.05)$.

Pada Tabel 3 menunjukkan bahwa semakin tinggi kosentrasi $\mathrm{CMC}, \mathrm{pH}$ sari buah Tomat semakin meningkat. Menurut Priyono (2002), bahwa penambahan kosentrasi CMC akan meningkatkan nilai $\mathrm{pH}$ hal ini disebabkan CMC mempunyai sifat meningkatkan nilai $\mathrm{pH}$.

\section{Warna Merah (a*) Sari Buah Tomat}

Uji warna sari buah tomat dengan mengunakan Colorimeter Hunterlab Ultra scan Vis 1297. Dari hasil pengamatan yang dilakukan terhadap warna nilai merah (a*) sari buah tomat, didapat nilai rata-rata 13.32 sampai dengan 13.95. Nilai warna a* sari buah tomat tertinggi pada perlakuan penambahan CMC $0.20 \%$ dengan pemanasan 30 menit yaitu 13.95, sedangkan nilai warna merah $\left(\mathrm{a}^{*}\right)$ terendah pada perlakuan Penambahan CMC $0.1 \%$ dengan pemanasan 15 menit yaitu 13.2.

Hasil analisis statistik Anova menunjukan bahwa penambahan kosentrasi CMC dan lama pemanasan tidak memberi pengaruh yang nyata, interaksi keduanya juga tidak berpengaruh terhadap warna merah $\left(\mathrm{a}^{*}\right)$ sari buah tomat. Hal ini diduga karena masing masing perlakuan mempunyai kosentrasi sari tomat yang sama.

\section{Organoleptik Sari Buah Tomat}

Uji hedonik dilakukan terhadap sari buah tomat yang telah dibuat dengan semua perlakuan kepada 15 panelis untuk di minta tanggapanya terhadap produk sari buah tomat, dengan skala kesukaan 1 sampai 5, mulai dari sangat tidak suka, tidak suka, netral, suka hingga sangat suka. Skala hedonik yang digunakan ditransfor masikan menjadi skala numerik dengan 
angka terendah hingga angka tertiggi. Hal ini dilakukan untuk mengetahui adanya perbedaan tingkat kesukaan antar perlakuan. Hasil pengamatan tersebut meliputi rasa, warna dan aroma.

\section{Rasa}

Rasa merupakan suatu variabel penentu dalam tingkat penerimaan panelis terhadap suatu produk. Rasa berhubungan dengan komponen bahan pangan yang dapat ditangkap oleh indra perasa (lidah). Rerata skor kesukaan panelis terhadap rasa sari buah tomat dengan penambahan kosentrasi CMC dan lama pemansan yaitu 2.87 - 4.4, rasa sari buah tomat tertinggi terdapat pada perlakuan penambahan CMC $0.10 \%$ dengan pemanasan 10 menit yaitu 4.4 , sedangkan hasil rasa sari buah tomat terendah terdapat pada perlakuan penambahan CMC $0.20 \%$ dengan pemanasan 30 menit yaitu 2.87.

Hasil analisis statistik dengan menggunakan uji nonparametric tes diperoleh nilai pringkat 53.83 - 134.40. Kombinasi antara kosentrasi CMC dan lama pemanasan mempengaruhi rasa dari sari buah tomat. Pengaruh Kosentrasi CMC dan lama pemanasan terhadap rasa sari buah tomat dapat dilihat pada Tabel 4.

Tabel 4. Nilai Peringkat rasa Sari Buah Tomat

\begin{tabular}{cr}
\hline Perlakuan & $\begin{array}{c}\text { Rata-rata } \\
\text { (Rangking) }\end{array}$ \\
\hline CMC 0.10\% pemanasan 10 menit & 134.40 \\
CMC 0.10\% pemanasan 15 menit & 83.47 \\
CMC 0.10\% pemanasan 20 menit & 95.07 \\
CMC 0.10\% pemanasan 30 menit & 62.43 \\
CMC 0.15\% pemanasan 10 menit & 113.57 \\
CMC 0.15\% pemanasan 15 menit & 123.90 \\
CMC 0.15\% pemanasan 20 menit & 82.10 \\
CMC 0.15\% pemanasan 30 menit & 93.43 \\
CMC 0.20\% pemanasan 10 menit & 79.03 \\
CMC 0.20\% pemanasan 15 menit & 81.67 \\
CMC 0.20\% pemanasan 20 menit & 83.10 \\
CMC 0.20\% pemanasan 30 menit & 53.83 \\
\hline
\end{tabular}

Tabel 4 menunjukkan bahwa. kosentrasi CMC $0.1 \%$ dan lama pemanasan 10 menit merupakan perlakuan yang paling disukai dengan perolehan skor peringkat tertinggi yaitu 134.40, sedang penambahan kosentrasi CMC $0.2 \%$ dan lama pemanasan 30 menit merupakan perlakuan yang paling tidak disukai dengan perolehan skor peringkat Terendah yaitu 53.83. Hal ini diduga karena kosentrasi CMC $0.2 \%$ sari buah tomat terlalu kental. 


\section{Warna}

Rerata skor kesukaan panelis terhadap warna sari buah tomat yaitu 3.60 - 4.33, warna sari buah tomat tertinggi terdapat pada perlakuan penambahan CMC $0.10 \%$ dengan pemanasan 10 menit yaitu 4.33, sedangkan hasil warna sari buah tomat terendah terdapat pada perlakuan penambahan CMC $0.20 \%$ dengan pemanasan 10 menit yaitu 3.60.

Hasil analisis statistik dengan menggunakan uji nonparametric tes diperoleh nilai peringkat 67.00 - 120.30. Hasil uji bahwa kosentrasi dan lama pemansan tidak mempengaruhi warna sari buah tomat. Hal ini diduga karena penambahan kosentrasi CMC tidak mempengaruhi warna karena $\mathrm{CMC}$ memiliki sifat serbuk berwarna putih. dan ketika dipanaskan berwarna transparan sehingga warna sari buah tomat tidak terpengaruh oleh penambahan CMC dengan kosentrasi $0.1 \%-0.2 \%$.

\section{Aroma}

Rerata skor kesukaan panelis terhadap aroma sari buah tomat dengan penambahan kosentrasi $\mathrm{CMC}$ dan lama pemansan yaitu 3.35 - 4.13, aroma sari buah tomat tertinggi terdapat pada perlakuan penambahan CMC $0.10 \%$ dengan pemanasan 10 menit yaitu 4.13, sedangkan hasil aroma sari buah tomat terendah terdapat pada perlakuan penambahan CMC $0.20 \%$ dengan pemanasan 30 menit yaitu 3.53.

Hasil analisis statistik dengan menggunakan uji nonparametric tes diperoleh nilai peringkat 73.63 - 117.53. Hasil uji menunjukan bahwa kosentrasi dan lama pemansan tidak mempenga ruhi aroma sari buah tomat. Hal ini diduga karena aroma sari buah tomat sangat dominan aroma tomat. Masing masing perlakuan mempunyai kosen trasi perasan sari tomat yang sama sehingga masing-masing perlakuan memikil aroma yang sama. Ditambah kan oleh Fitriyaningtiyas (2015) bahwa, CMC berbentuk bubuk warna putih, tidak berasa dan tidak berbau sehingga tidak mempengaruhi aroma produk.

\section{KESIMPULAN}

Kesimpulan yang didapat dari hasil penelitian adalah sebagai berikut: 
1. Kosentrasi $\mathrm{CMC}$ memberikan pengaruh nyata terhadap kadar, $\mathrm{pH}$ dan viskositas sari buah tomat.

2. Lama pemanasan memberikan pengaruh nyata pada kadar likopen sari buah tomat

3. Interaksi antara kosentrasi $\mathrm{CMC}$ dan lama pemanasan berpengaruh nyata terhadap kadar likopen

\section{DAFTAR PUSTAKA}

Astuti, D.W. 2004 Pembuatan Sari Buah Tomat (Lycopersicum esculentum Mill) dengan Variasi Macam Dan Jumlah Bahan Penstabil. Universitas Diponegoro. Semarang.

Badan Pengawasan Obat dan Makanan Republik Indonesia. 2006. Keputusan Kepala badan Pengawasan Obat dan Makanan Republik Indonesia Tentang Katagori Pangan, Badan Pengawas Obat dan Makanan Indonesia. Jakarta.

Fitriyaningtiyas, S.I. dkk 2015. Pengaruh Penggunaan Lesitin dan CMC terhadap Sifat Fisika, Kimia, dan Organoleptik Margarin Sari Apel Manalagi (Malus sylvestris Mill) Tersuplementasi Minyak Kacang Tanah. Jurnal Pangan dan Agroindustri. 3(1): 226-236.

Jevic, U.C.O. etc. 2003. Lycopen Inhibits The Growth of Normal Human Prostate Ephitelial Cells in Vitro. 3356-3360.
Kamal, N. 2010. Pengaruh Bahan Aditif CMC (Carboxyl Methyl Cellulose) terhadap Beberapa Parameter Pada Larutan Sukrosa, Jurnal Teknologi. 1(17): 78-84.

Oberoi, D.P.S., etc. 2015. Prediction Of lycopene degration during dehydration of watermelon pomance, Jour nal of the Saudi Society of Agricultural Sciences. 16(1) : 97-103.

Pracaya. 1998. Bertanam Tomat. Kanisius. Yogyakarta.

Prayitno, S. 2002. Aneka Olahan Terung. Kanisius. Yogyakarta.

Purwadi, dkk. 2007. Pengaruh Lama Waktu Ozonisasi Terhadap Umur Simpan Buah Tomat (Lycopersicum esculntum Mill.). Pusat Teknologi Akselerator dan Proses Bahan. 234242.

Radhakrisnan, M. 2017. 18 Amazing Benefits Of Lycopene For Skin, Hair and Health. World's Largest Website for Womens.

Shi, dkk.1999. Lycopene Degradation and Isomerization in Tomato Dehydration, Food Research Internationa. 15-21.

Standard Nasional Indonesia (SNI).1998. Sari buah Tomat. Badan Standarisasi Nasional. Jakarta

Story, dkk. 2010. An Update on the Health Effects of Tomato Lycopene. The Annual Review of Food Science and Technology. 